\title{
同期発電機の脱調時の磁束挙動に基づく過渡
}

\section{特性 一過渡時の特性表現の物理的意味—}

$\begin{array}{lllll}\text { 正員引原 } & \text { 隆 } & \text { (関酉大) } \\ \text { 正員上 } \text { 田 } & \text { 睆 亮 } & \text { (京都大) } \\ \text { 正 員上之園 } & \text { 親 佐 } & \text { (京都大) }\end{array}$

\section{1.はじめに}

同期発電機の動作特性に関する研究は 19 世紀末に 始まり，現在むなお続りられている。てれらの研究の 主要な目的は, 電力系統の安定運用のために発電機特 性を把握することにある。近年, 電子計算機の発達に 伴い，電力系統の安定度解析が数多く行われている。 ところが，乙れらの解析結果が過渡状態においては実 系統の㬰測結果と必ずしす一致しないととが指摘され ている。

従来の同期発電機の特性表現は，発電機をブラック ボックスとして端子量から等価回路的に求められてき た。一方，発電機を支配する主要な物理量は発電機の 内部磁束であり，その特性表現において重要な役割を 有している。しかし，過渡時の特性表現が現実の発電 機動作において生じている磁束の挙動を正確に表して いるか否加の検討忙，通常負荷運転中の発電機に関し ては，ほとんど行われていないと言っても過言ではな い。このため, 良好な解析結果を得るための特性表現 の補正が，必ずしす現実に生じている発電機内部の物 理現象に合致していない。

著者引は発電機内部磁束儿着目し，発電機の動作中 に内部磁束が測定できるように探りコイルを取付けた 小形同期発電機を製作し，その実測した空げき磁束分

\footnotetext{
Transient Characteristics of a Synchronous Generator Based on the Behavior of Magnetic Flux at the State of Asynchronization - Physical Meaning of Transient Characteristic Expression. By Takashi Hikiharo, Member (Department of Electrical Engineering, Kansai University), Yoshisuke Ueda, Member (Department of Electrical Engineering, Kyoto University) \& Chikasa Uenosono, Member (Emetitus Professor of Kyoto University).

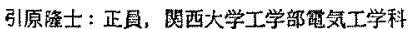

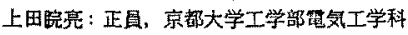
上之圆親佐：正貝，京都大学名謷授
}

布に基づいて発電機の特性を解明する一速の研究を行 っている(1) (6)。本論文では，既汇得られている過渡 時において探りコイル誘起電厌より空げき磁束密度を 求める算定法 ${ }^{(6)}$ を, 脱調発展過程の空げき磁束分布の 算定に適用する。そして，得られた結果より脱調時の 同期発電機の特性表現を磁束挙動に基ついて検討し， その物理的意味を説明する。以下の章では，まず第 2 章において実験に用いた供試発電機㧍よび実験の設定 条件について述べる。次に，第 3 章で探りコイルを用 いて測定した空げき磁束密度を用いて，発電機の過渡 時の動作特性を検討する方法について述べ，第 4 章で 脱調時の諸量の測定結果および算定結果を示す。更に 第 5 章では，第 4 章に得た銷交磁束と各電流の変化に 関して実験式を導き，脱調時の同期発電機の特性表現 を詳細に検討し，その物理的意味を明らかにする。そ して，この結果より従来の端子量に基づく特性表現の 表している物理現象について明らかにする。最後の第 6 章において本実験て得られた結果を要約する。

本論文は, 従来々の内部磁束之の関連加ら十分な検 討がなされていなかった同期発電機の過渡特性を，空 げき磁束の测定に基づいて検討したものである。この 結果，脱調時において従来の特性表現が表しているの は，発電機の瞬時特性ではなく，回転子の滑りに伴う 振動特性であり, 従っててのときの過洨インダクタン スは従来の意味の過渡インダクタンスと異なった物理 的意味を有するととを明らかにした。とこに得られた 結果は, 同期発電機の過渡特性に関して, 従来見過さ れていた点を明らかにしており，今後の系統の過渡安 定度解析の改善牦重要な手掛りを与えているすのと考 えられる。 


\section{2. 実験の概要}

〈2.1〉供試発電機 実験に使用した同期発電機 は，図1亿示す 4 極回転界磁形突極機である。定格は 容量 $6 \mathrm{kVA}$, 電王 $220 \mathrm{~V}$, 電流 $15.7 \mathrm{~A}$, 力率 0.9 (遅れ), 回転数 $1,800 \mathrm{rpm}$ である。電機子巻線は三 相で，巻線方式は重ね巻，分布巻，短節巻，整数ス口 ット巻が採用されている。每極每相のスロット数は 3 で斜めスロットが用いら扎ており，相間接椟は星形で ある。

供試発電機には図 1 に示すように，電機子崡頭部に 磁束計測用探りコイルが設りられている。また，制動 卷線は着脱可能である。この発電機は $154 \mathrm{kV}$ 系統に おける 13MVA の発霜機を模擬して製作されたすの であり，実機相当の無負荷飽和特性之短絡比を持たせ るために，界磁鉄心部にイスムス (isthmus) が設けら れている。そして, 界磁電流 $i_{f}=3.2 \mathrm{~A}$ のさ公称界 磁誘粰起電力 $220 \mathrm{~V}$ を発生する。この飽和特性など については，文献(5)を参照されたい。な㧍，供試発 電機ば直流電動機で駆動されており，その定格は容量 $15 \mathrm{~kW}$ ，電在 $220 \mathrm{~V}$ である。本システムの慣性定数 は, $G D^{2}$ で $3.65 \mathrm{~kg} \cdot \mathrm{m}^{2}$ である。そのはか電気試験 法(7)に従って得た本供試発電機の定数を表 1 儿示す。

\section{〈2.2〉実験系統実験は，供試発電機を用いて} 图 2 亿示す一機無限大系統安構成して行う。図中，変 王器 Tr. 1 の定格は容量 $6 \mathrm{kVA}$, 一次/二次電圧 $220 /$ $3,300 \mathrm{~V}$ であり，Tr.2 のそれらは $20 \mathrm{kVA}, 3,300 /$ $210 \mathrm{~V}$ である。送電線け $6 \mathrm{kVA}, 220 \mathrm{~V}$ をべースとし て 40\% 一回線とし，無限大母線として $210 \mathrm{~V}, 60 \mathrm{~Hz}$ の配電線を用いている。

〈2.3〉設定条件 本墖文で検討の対象としてい る脱調状態を発生させるために，前節の系統を用いて 次の操作を行う。まず,定態安定領域内で動作している

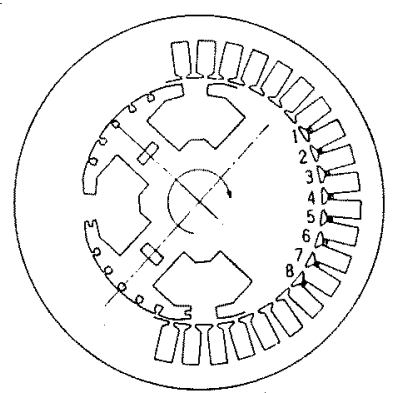

図 1 供試発電機断面図拉よび探りコイル 取付け位犆

Fig. 1. A cross section of the tested generator and the disposition of the search coils.
表 1 供試発電機の諸定数

Table 1. Machine constants of tested generator.

\begin{tabular}{|c|c|c|c|}
\hline 㙨 器 定 数 & & 定 & 值 \\
\hline 㨁軸過渡インダタタンス & $L_{d^{\prime}}$ & $0.0067 \mathrm{H}$ & $31.5 \%$ \\
\hline 柈軸過渡 インダクタンス & $L_{q^{\prime}}$ & $0.0163 \mathrm{H}$ & $76.1 \%$ \\
\hline 電機子洔定数 & $T_{a}$ & \multicolumn{2}{|c|}{$0.024 \mathrm{~s}$} \\
\hline 短絡通湤洔定数 & $T_{d^{\prime}}$ & \multicolumn{2}{|c|}{$0.104 \mathrm{~s}$} \\
\hline 開路㭙定数 & $T_{d 0^{\prime}}$ & \multicolumn{2}{|c|}{$0.434 \mathrm{~s}$} \\
\hline
\end{tabular}

(注) パーセント数倠は $6 \mathrm{kVA} ， 220 \mathrm{~V}$ をベースとしたものである。

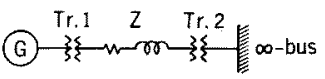

图 2 実験系統

Fig. 2. Experimental system.

供試発電機の界磁電流を一定 (3.2A) 亿保つ。次に, 直 流機からの機珹入力を準静的に堌し，発電機出力を定 態安定極限電力近くまで増加する。その後，機械入力 をわずかに増加すると回転子に㗢くトルクがバランス を失い，回転子は加速を始める。乙の際，界磁電流の 供給は定電圧源装置を用いて行い，AVR などの励磁 制御は行っていない。また，直流機は発電機の脱調後 定電圧運転を行い，速度制御は行わない。更に本実験 に抢いては，供試発電機の制動巻線を取外している。

\section{3. 解析の概要}

〈3.1〉 2 極機モデル 供試発電機は 4 極機であ るが，空げき磁束の空間分布表現亡出力の麗気的位相 表現の対応を容易にするために，図 3 に示す 2 極機モ

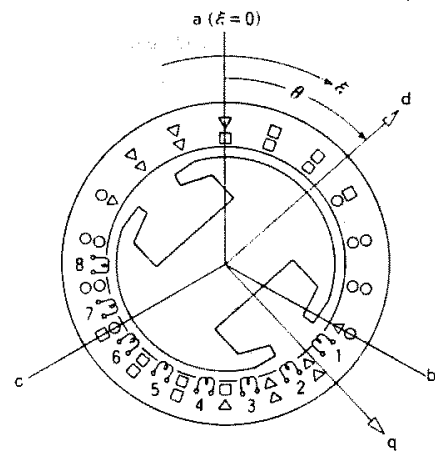

m : Search coil

o :Phase-a conductor

a :Phase.b conductor

$\triangle$ :Phase c conductor

図 3 二極機モデルと座標系

Fig. 3. The model of two salient pole type genertator and the coordinates.

T. IEE Japan, Vol. 108-D, No. 3, '88 
デルを埒入する。このモデルにおいて，二つの座標系 $\xi, \theta(\mathrm{rad})$ を導入する。 で， $\theta$ は回転子の直軸位置を表す座標系である。とれ らの座標系の原点は $a$ 相巻線軸におく。ここに埒入し た $\theta$ は時間の関数であり，次式で表現する。

$$
\theta(t)=\omega_{0} t+\delta(t)
$$

ここで, $\omega_{0}[=120 \pi(\mathrm{rad} / \mathrm{s})]:$ 無限大母線の

基準角周波数, $\delta(t)$ : 相差角

とのとき，回転子の角速度は次式で表される。

$$
\frac{d \theta(t)}{d t}=\omega_{0}+\frac{d \delta(t)}{d t}
$$

〈3.2〉空げき磁束密度の表現過渡時の空げき 磁束密度分布は，定態時における表現より次式で表す ことができる(1)(6)。

$$
\begin{aligned}
B(\xi, t)= & \sum_{n=1,3,5, \ldots}\left[B_{n c}(t) \cos n\{\xi-\theta(t)\}\right. \\
& \left.+B_{n s}(t) \sin n\{\xi-\theta(t)\}\right] \ldots \ldots(
\end{aligned}
$$

ここで, $B_{n c}(t), B_{n s}(t):$ それぞれ空げき磁束

密度の第 $n$ 時間・空間高調波 $\cos , \sin$ 成分

(3)式は回転子上に静止する磁束成分のみを表してお り，実際に空げきには回転子上に静止しない磁束成分 香存在する。これらの磁束密度の各成分姑, 複数本の 偨りコイルの誘起電王を用いるこよにより正碓に分離 抽出できる。その方法の詳細については文献（6)を参 照されたい。しかし，回転子上に静此しない磁束成分 は量的には少なく，また発電譏出力に影響を与えない ので無視できる。従って，空げき磁束密度は(3)式の ように回転子上に静止する磁束成分のみで表す。

〈3.3〉端子量の表現 （3）式の空げき磁束密度 表現を用いると，諸端子量は次のようになる。まず， 端子(相)電圧は次式で与えられる。

$$
\left.\begin{array}{l}
e_{a t}(t)=-\sqrt{2} E_{t}(t) \sin \left\{\theta(t)+\delta_{t}(t)\right\} \\
e_{s t}(t)=-\sqrt{2} E_{t}(t) \sin \left\{\theta(t)+\delta_{t}(t)-2 \pi / 3\right\} \\
e_{c t}(t)=-\sqrt{2} E_{t}(t) \sin \left\{\theta(t)+\delta_{t}(t)-4 \pi / 3\right\}
\end{array}\right\}
$$

ここで, $\delta_{t}(t):$ 端子電圧と $d$ 軸との電気的位 相差

また，䉓機子䉓流は次式で与えられる。

$$
\left.\begin{array}{l}
i_{a}(t)=-\sqrt{2} I_{a}(t) \sin \{\theta(t)+\gamma(t)\} \\
i_{b}(t)=-\sqrt{2} I_{a}(t) \sin \{\theta(t)+\gamma(t)-2 \pi / 3\} \\
i_{c}(t)=-\sqrt{2} I_{a}(t) \sin \{\theta(t)+\gamma(t)-4 \pi / 3\}
\end{array}\right\}
$$

ここで, $r(t):$ 内部力率角

更に，無限大母線電圧を次式で表す。

$$
\left.\begin{array}{l}
e_{\infty \infty}(t)=-\sqrt{2} E_{\infty} \sin \omega_{0} t \\
e_{b \infty}(t)=-\sqrt{2} E_{\infty} \sin \left(\omega_{0} t-2 \pi / 3\right) \\
e_{c \infty}(t)=-\sqrt{2} E_{\infty} \sin \left(\omega_{0} t-4 \pi / 3\right)
\end{array}\right\}
$$

こ机らの諸量において，振偪上位相は脱調時には時間 的に緌やかに変化する量上して报うととができる(6)。

(4) (6)式の各三相成分に次の $d q$ 変換を推す。

$$
\begin{aligned}
{\left[\begin{array}{l}
d \\
q
\end{array}\right]=} & \frac{2}{3}\left[\begin{array}{cc}
\cos \theta(t) & \cos \left\{\theta(t)-\frac{2}{3} \pi\right\} \\
-\sin \theta(t)-\sin \left\{\theta(t)-\frac{2}{3} \pi\right\}
\end{array} *\right. \\
& * \cos \left\{\theta(t)-\frac{4}{3} \pi\right\} \\
& \left.-\sin \left\{\theta(t)-\frac{4}{3} \pi\right\}\right)\left[\begin{array}{l}
a \\
b \\
c
\end{array}\right] \ldots \ldots(7
\end{aligned}
$$

その結果, 上述の諸罝の $d q$ 成分が次式で表される。

$$
\left.\left.\begin{array}{l}
e_{d t}(t)=-\sqrt{2} E_{t}(t) \sin \delta_{t}(t) \\
e_{q t}(t)=\sqrt{2} E_{t}(t) \cos \delta_{t}(t)
\end{array}\right\} \begin{array}{l}
i_{d}(t)=-\sqrt{2} I_{a}(t) \sin \gamma(t) \\
i_{q}(t)=\sqrt{2} I_{a}(t) \cos \gamma(t)
\end{array}\right\} . .
$$

これらの式を用いるととにより，测定值加ら各 $d, q$ 軸 成分を毎周期ごとに算定することができる。

\section{〈3.4〉電機子卷線鎖交磁束の算定法 電機子巻} 線鎖交磁束は，図 4 亿示す電機子巻線の分布領域にお いて，空け゚き磁束密度を皘尔することにより求めるこ とがでさる。 $a$ 相巻線鎖交磁束 $\phi_{a}(t)(\mathrm{Wb})$ は次式で 得ら扎 (1)。

$$
\begin{aligned}
\phi_{a}(t)= & 16 \sum_{m=0,1,2} \int_{0}^{l} d \zeta \\
& \times \int_{-(\pi / 2)-(m-1) \alpha+(\alpha / l) \zeta}^{(\pi / 2)-m \alpha+(\alpha / l) \zeta} B(\xi, t) r d \xi \\
= & \sum_{n=1,3,5, \ldots} K_{n}\left\{B_{n c}(t) \cos n \theta(t)\right. \\
& \left.-B_{n s}(t) \sin n \theta(t)\right\} \ldots \ldots \ldots \ldots . . .11
\end{aligned}
$$

ここで,

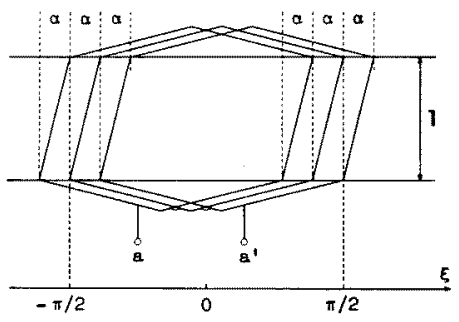

図 $4 a$ 相巻線分布図

Fig. 4. Distribution of phase- $a$ winding. 


$$
K_{n}=32 r l_{e} \frac{\sin \left(\frac{n \pi}{2}\right)(\sin n \alpha+\sin 2 n \alpha)}{n^{2} \alpha}
$$

ただし, $r(=0.1375 \mathrm{~m}):$ 電機子内半径, $l(=$ $0.13 \mathrm{~m})$ : 電機子韩長, $l_{\mathrm{c}}\left(=\kappa_{t} l, \kappa_{\mathrm{t}}=1.13\right)$ :

有效軸長， $\alpha(=\pi / 9 \mathrm{rad})$ ：スロッ卜角（電気 角)

同㥞の計算により, $b, c$ 相卷線鎖交磁束 $\phi_{b}(t), \phi_{c}(t)$ は 次式となる。

$$
\begin{aligned}
\psi_{b}(t)= & \sum_{n=1,3,5, \ldots} K_{n}\left[B_{n c}(t) \cos n\{\theta(t)\right. \\
& \left.\left.-\frac{2}{3} \pi\right\}-B_{n s}(t) \sin n\left\{\theta(t)-\frac{2}{3} \pi\right\}\right] \\
\psi_{c}(t)= & \sum_{n=1,3,5, \ldots} K_{n}\left[B_{n c}(t) \cos n\{\theta(t)\right. \\
& \left.\left.-\frac{4}{3} \pi\right\}-B_{n s}(t) \sin n\left\{\theta(t)-\frac{4}{3} \pi\right\}\right]
\end{aligned}
$$

従って，電機子巻線鎖交磁束の $d, q$ 軸各成分は (7) 式より次式で表される。

$$
\begin{aligned}
\psi_{d}(t)= & K_{1} B_{1 c}(t)+\left\{K_{5} B_{5 c}(t)+K_{7} B_{7 c}(t)\right\} \\
& \times \cos 6 \theta(t)-\left\{K_{5} B_{5 s}(t)\right. \\
& \left.+K_{7} B_{7 s}(t)\right\} \sin 6 \theta(t)+\cdots \\
\psi_{q}(t)= & K_{1} B_{1 s}(t)+\left\{-K_{5} B_{5 s}(t)\right. \\
& \left.+K_{7} B_{7 s}(t)\right\} \cos 6 \theta(t) \\
& +\left\{-K_{5} B_{5 c}(t)+K_{7} B_{7 c}(t)\right\} \\
& \times \sin 6 \theta(t)+\cdots
\end{aligned}
$$

上式において，第2 項目以下は $n \geqq 5$ で $K_{n}, B_{n c}(t)$, $B_{n s}(t)$ が小さいので無視できる。徒って， $\phi_{d}(t), \phi_{q}(t)$ として次式を得る。

$$
\left.\begin{array}{l}
\psi_{d}(t)=K_{1} B_{1 c}(t) \\
\psi_{q}(t)=K_{1} B_{1 s}(t)
\end{array}\right\}
$$

との(15)式を用いるととにより, 空げき磁束密度の時 間・空間基本波振幅加，電磁子巻線銷交磁束の $d, q$ 軸各成分を実験的に算定することができる。

\section{4. 実験結果}

本章では，供試発電機を用いて行った実験の諸量の 测定結果と算定結果を示す。ここに示す結果を用い て，次章で同期発電機の過渡特性を検討するにあたり， 〈2・4〉節に示した設定条件下で 5 回実験を絽返した。 しかし，それらの結果にはほとんど違いがないので， 本章ではそのうち一つの場合についてのみ示す。
〈4.1〉脱調時の諸量の変化供試発電機を前述 の設定条件下で脱謂させた場合に得られた諸端子量の 変化を図 5 亿示す。この結果は脱調発廊に伴う諸量の 時間变化を示している。まず，(a)因は回転子の回転 速度の变化を示して朽り, 脱調に伴い回転子が加速し ていく状態を示している。(b)図は端子電圧の寒効 值，（c）図は相差角，（d）図は電機子電流の䒠勃値， (e)図は内部力率角，(f)図は界磁電流，（g）図は電 気出力の变化を示している。特に，(c)，(e)図の位 相量代関しては，電気角 1 回転ごとの動作点の位置を 図中に○印で示した。これらの結果より，相差角と内 部力率角の絶対値が単調に增加していく棁子が明らか である。また，端子電圧，電機子電流，界磁電流およ び出力は, 回転子の同期角速度加らの滑り量加 $2 \pi$ 変 化する時間間隔で振動している。出力の变化より, 脱 調時汇おいて供試発電機は発電機状態（出力が正）上 電動機状態（出力が負）を交互に繰返しながら加速し ていく様子がわかる。

電機子電流については，図5(d), (e)の結果と, (9)式を用いることにより $d, q$ 各軸成分を算出でき る。その結果を図6に示す。これらについてむ図 5 と 同様に，回転子の滑りに伴う振動が見られる。

〈4-2〉電機子巻線鎖交磁束 過渡時において, 铹りコイル謤起電圧より空げき磁束密度の時間・空間 基本波成分を抽出する方法は，既に文献（6）飞おいて 得られており，その方法を本実験結果の処理に適用す る。更に，(15)式を用いて算出した電機子卷線銷交磁 束の $d, q$ 各朝成分の脱調時の発屡に伴う変動を図 7 に示す。と机らむ，図 5 亿示した端子量と同様に，回 転子の同期角速度加らの滑りに伴って振動を絽返す。 てのうち,$d$ 軸成分 $\phi_{a}(t) k は$ 振動開始後直流成分の 変化が見られる。一方，q 軸成分 $\psi_{q}(t)$ については直 流成分は一定である。ただし，ここで直流成分という のは，滑りに伴う振動の直流成分であって，出力の電 気的振動で見た変化の直流成分とは暴なる。

\section{5. 脱調時の同期発電機の特性に関する検討}

本章では，前章に得た実験結果に基づいて脱調時の 同期発電機の過渡特性について检討を加え，銷交磁束 之電流の関係を明確に表すととを試みる。以下の議論 は，三相突発短絡時の電流の変化の解析法(7)を，䬽調 洔の電流，鎖交磁束の回転子の滑りに伴う振動の解析 に㹡張適用したすのである。

\section{〈5・1〉 鎖交磁束と電流の関係}

（1）電流の実験式 脱調による振動の開始時刻 $t_{0}$ を電流值の時間変化の最初の極値の時刻とする。こ 


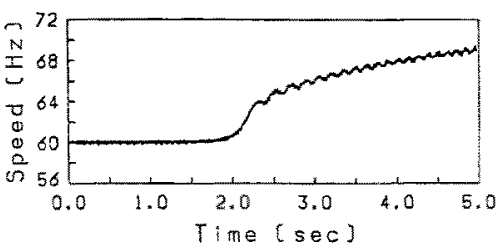

(a)

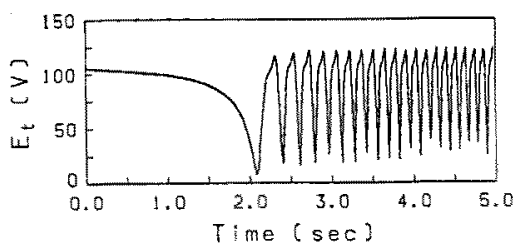

(b)

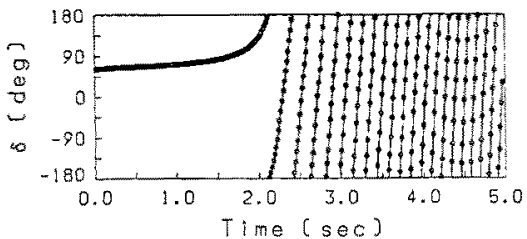

(c)

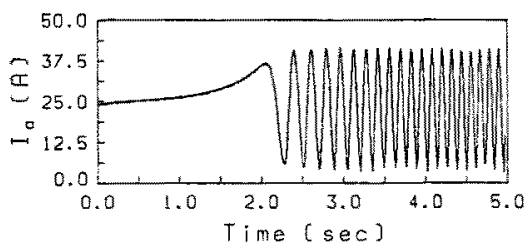

(d)

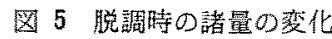

Fig. 5. Development of asynchronization.

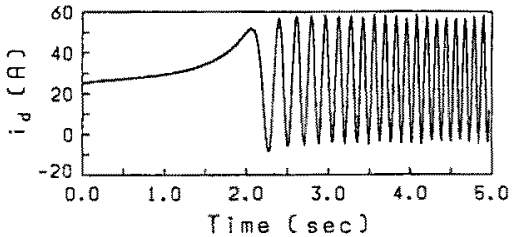

(a)

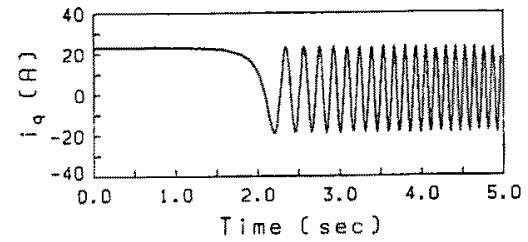

(b)

図 6 脱调時の電機子電流 $d, q$ 轴成分の変化

Fig. 6. Change of the $d$ - and $q$-axis components of the armature current at the state of asynchronization.

電学論 $D, 108$ 巻 3 号, 昭 63

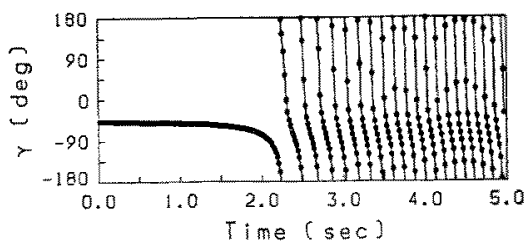

(e)

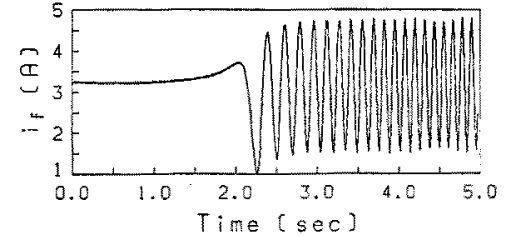

(f)

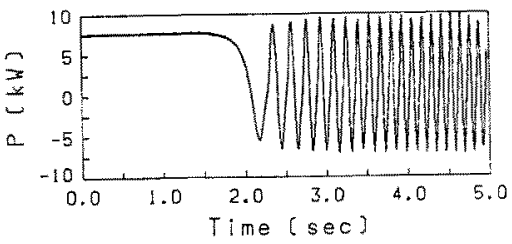

(g)

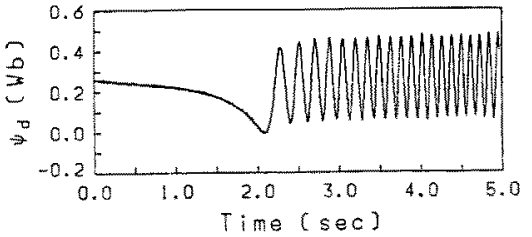

(a)

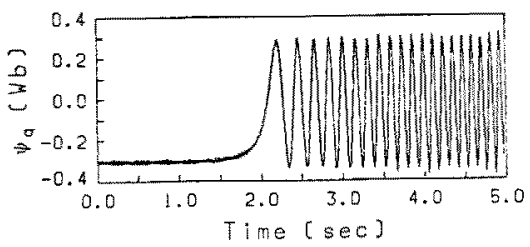

(b)

図 7 脱铜時の電機子巻線銷交磁束 $d, q$ 軸 成分口学化

Fig. 7. Change of the $d$ - and $q$-axis components of the armature fux linkage at the state of asynchronization. 
のとき $t \geq t_{0}$ における脱謂時の電流の実験式を检砷す る。まず，界磁電流 $i_{f}(t)$ は次式で表すととができる。

$$
\begin{aligned}
& i_{f}(t)=i_{f \mathrm{DC}}(t)+i_{f \mathrm{AC}}(t) \\
& i_{f D C}(t)=i_{f}(0)-I_{f D C} e^{-\left(1 / T_{f}\right)\left(t-t_{0}\right)} \\
& i_{f \mathrm{AC}}(t)=I_{f \mathrm{ACC}} \cos \omega_{s}\left(t-t_{0}\right) \\
& \text { ただし， } \omega_{s}=d \delta(t) / d t \text { で回転子の滑り角速度， } \\
& T_{f}: \text { 時定数 }
\end{aligned}
$$

上式中の漂字 DC，AC の备量は，それぞれ回転子の 同期角速度加らの滑りに伴う $i_{s}(t)$ の振動の直流成 分，交流成分を表している。次に，電機子電流の実效 值 $I_{a}(t)$ の実験式は次式となる。

$$
\begin{aligned}
I_{a}(t)= & I_{a \mathrm{DC}}(t)+I_{a \mathrm{AC}}(t) \\
I_{a \mathrm{DC}}(t)= & I_{a \mathrm{DC}}\left(t_{0}\right) \\
I_{a \mathrm{AC}}(t)= & \left\{A_{1}-A_{2} e^{-\left(1 / T_{a}\right)\left(t-t_{0}\right)}\right\} \\
& \times \cos \omega_{s}\left(t-t_{0}\right) \\
\text { ただし, } & T_{a} \text { : 時定数 }
\end{aligned}
$$

とれを， (7)式を用いて $d, q$ 変換して得た電機子電 流の $d, q$ 軸成分について検討すると， $t \geqq t_{0}$ において $d$ 軸電流 $i_{d}(t)$ の実䮦式は次式となる。

$$
\left.\begin{array}{l}
i_{d}(t)=i_{d \mathrm{DC}}(t)+i_{d \mathrm{AC}}(t) \\
i_{d \mathrm{DC}}(t)=i_{d \mathrm{DC}}(\infty)-I_{d \mathrm{DC}} e^{-\left(1 / T_{a d}\right)\left(t-t_{0}\right)} \\
i_{d \mathrm{AC}}(t)=I_{d \mathrm{AC}} \cos \omega_{s}\left(t-t_{0}\right)
\end{array}\right\}
$$

ここで， $T_{a d}: d$ 軸成分の時定数

同様に $q$ 軸成分 $i_{q}(t)$ の㬰験式は次式となる。

$$
\left.\begin{array}{l}
i_{q}(t)=i_{q \mathrm{DC}}(t)+i_{q \mathrm{AC}}(t) \\
i_{q \mathrm{DC}}(t)=i_{q \mathrm{DC}}\left(t_{0}\right) \\
i_{q \mathrm{AC}}(t)=-I_{q \mathrm{AC}} \sin \omega_{s}\left(t-t_{0}\right)
\end{array}\right\}
$$

以上の実験式の各定数は，〈2・3〉節に示した設定条件 下で実験を 5 回繰返して求めた。その結果の平均をと って得た各定数值它表 2 亿示す。

（2）鎖交磁束の実験式 電機子巻線鎖交磁束の $d, q$ 軸成分の脱調時におりる变化の寒験式のうち $d$

\begin{tabular}{|c|c|c|c|}
\hline 倍 数 & 算定篗 & 倸 数 & 䇣定倠 \\
\hline$\psi_{d \mathrm{DC}(\infty)}$ & $0.256 \mathrm{~Wb}$ & $\psi_{q} \mathrm{DC}\left(t_{0}\right)$ & $-0.028 \mathrm{~Wb}$ \\
\hline$\Psi_{d \mathrm{DC}}$ & $0.075 \mathrm{~Wb}$ & $\Psi_{q \mathrm{AC}}$ & $0.32 \mathrm{~Wb}$ \\
\hline$\Psi_{d A C}$ & $0.2 \mathrm{~Wb}$ & & \\
\hline$T_{p d}$ & $0.31 \mathrm{~s}$ & & \\
\hline
\end{tabular}
軸成分 $\psi_{d}(t)$ は $t \geqq t_{0}$ において次式で表される。

$$
\left.\begin{array}{l}
\psi_{d}(t)=\phi_{d \mathrm{DC}}(t)+\phi_{d \mathrm{AC}}(t) \\
\psi_{d \mathrm{DC}}(t)=\phi_{d \mathrm{DC}}(\infty)-\Psi_{d \mathrm{DC}} e^{-\left(1 / T_{p d}\right)\left(t-t_{0}\right)} \\
\phi_{d \mathrm{AC}}(t)=-\psi_{d \mathrm{AC}} \cos \omega_{s}\left(t-t_{0}\right)
\end{array}\right\}
$$

ただし， $T_{p d}$ : 時定数

同様に， $\phi_{q}(t)$ につては次式で表される。

$$
\left.\begin{array}{l}
\psi_{q}(t)=\psi_{q \mathrm{DC}}(t)+\psi_{q \mathrm{AC}}(t) \\
\psi_{q \mathrm{DC}}(t)=\psi_{q \mathrm{DC}}\left(t_{0}\right) \\
\phi_{q \mathrm{AC}}(t)=\psi_{q \mathrm{AC}} \sin \omega_{s}\left(t-t_{0}\right)
\end{array}\right\}
$$

\section{装 2 電流に関する実験式の定数}

Table 2. Constants in the experimental equations of the field and armature currents.

\begin{tabular}{l|c|l|c}
\hline 係 数 & 算 定 值 & 係 数 & 算 \\
\hline$i_{f}(0)$ & $3.2 \mathrm{~A}$ & $I_{a} \mathrm{DC}\left(t_{0}\right)$ & $22.6 \mathrm{~A}$ \\
$I_{f \mathrm{DC}}$ & $1.14 \mathrm{~A}$ & $A_{1}$ & $18.8 \mathrm{~A}$ \\
$I_{f \mathrm{AC}}$ & $1.64 \mathrm{~A}$ & $A_{2}$ & $4.8 \mathrm{~A}$ \\
$T_{f}$ & $0.32 \mathrm{~s}$ & $T_{a}$ & $0.23 \mathrm{~s}$ \\
\hline$i_{d \mathrm{DCC}}(\infty)$ & $26.2 \mathrm{~A}$ & $i_{q} \mathrm{DC}\left(t_{0}\right)$ & $2.1 \mathrm{~A}$ \\
$I_{d \mathrm{DC}}$ & $7.0 \mathrm{~A}$ & & \\
$I_{d \mathrm{AC}}$ & $32.0 \mathrm{~A}$ & $I_{q \mathrm{AC}}$ & $21.2 \mathrm{~A}$ \\
$T_{a d}$ & $0.23 \mathrm{~s}$ & & \\
\hline
\end{tabular}

表 3 電機子巻線鎖交磁束に関する奏験式の定数

Table 3. Constants in the experimental equations of the armature flux linkages.

以上の実験式の定数は，前節と同様に同一設定条件下 で実験を 5 回繰返し，その結果を平均して求めた。そ の算定值を表 3 にまとめて示す。

(3) 検 討 罘に述へたように, 同期発電機の 過渡特性丧現に関しては数多くの研究がなされている が，その多くは三相突発短絡に関するものである。本 諭文で示したように，脱調時における詳細な検討を 行った例は少ない。前項で得た界磁電流，電機子電流 の奏験式は，三相突発短絡の場合と同形式である(3)。 ただし，三相突発短絡の場合，滑り速度が回転速度に 一致するが，脱調時においては，回転子の回転速度が 图 5（a）に示すように徐々に增加し，乙の増加分加滑 り速度となる。従って, 滑りに伴う振動周期は時間経 過と共に短くなっていく。また，三相突発短絡では短 絡值相による䉓流波形の違いがあるが，脱調時におい ては実験ケースによる電流波形の違いを生じないの で，繰返した実験の結果の処理が容易となる。

前項までに導いた実験式は，鎖交磁束と麗流の関係 に関して多くの情解を与えている。まず，前項に示し た各值の振動は，回転子の加速に伴い周期が减少して いるにあかかわらず，実験式に示したように直流成分 にはこの影響が現れない。これは，直流成分が回転子 の同期角速度加らの滑りに伴う回転磁界によらないこ とを示している。従って，電機子巻線鎖交磁束の $d$ 軸 睨流成分は，界磁電流と電機子電流 $d$ 朝成分双方の直 流成分に依存していると考究られるが，表 3 に得た時 定数加ら検討すると，主として界磁電流に依存してい 
ると判断できる。これは濐目している鎖交磁束が，空 げきにおいてトルク伝達に関与している磁束のみで, 界磁電流の寄与が $d$ 軸成分のみであることから容易に 理解できる(1)。この成分中に，電機子電流の直流成分 の影櫂も現れていると考えられるが，ほとんど無視で きる。一方，電機子電流のd軸直流成分は，固定子ス ロット内に脱調発生時に起磁力の対向によって押込ま れた磁束（䨖機子漏れ磁束）が，減少していく際に生 じる起磁力に対応する量と考えられる。従って，(18) 式中の $T_{a d}$ は電機子漏孔磁束の減少の時定数之栲え られる。同しく，電機子巻線銷交磁束のd軸交流成分 估，界磁電流と電機子電流 $d$ 軸成分双方の交流成分に 上り生じることは明らかであるが，その双方の奇与関 係については，本実験結果から判断することは困難で ある。しかし，この值は双方の電流から空げきに生じ る回轱磁界の起磁力比に対応するあのであり，重要な 量であると考えられる。

一方, 電機子巻線銷交磁束の $q$ 軸成分は, 電機子電 流の $q$ 軸成分のみに依存していると考えられる。良っ て，各々の直流成分，交流成分どうしが詨芯する。

\section{$\langle 5 \cdot 2\rangle$ 過渡封のインダクタンス}

（1）銷交磁束と電流の関係式前節で得た銷交 磁束と電流の㬰験式と検討結果より，過渡㭙の電機子 巻線鎖交磁束の $d, q$ 軸各成行は, $t \geqq t_{0}$ に打いて次式 で与えられる。

$$
\left.\begin{array}{rl}
\phi_{d}(t)= & L_{d f} \mathrm{DC}_{i_{f \mathrm{DC}}(t)-L_{d f^{\mathrm{AC}}} i_{f \mathrm{AC}}(t)} \\
& -L_{d}{ }^{\mathrm{AC}} i_{d \mathrm{AC}}(t) \\
\phi_{q}(t)= & -L_{q}{ }^{\mathrm{DC}} i_{q \mathrm{DC}}(t)-L_{q}{ }^{\mathrm{AC}} i_{q \mathrm{AC}}(t)
\end{array}\right\}
$$

ととで, 各係数はそれぞれ各電流の鎖交磁束への寄与 を表すインダクタンス相当量であり，澺字 DC, $\mathrm{AC}$ は 各電流の回転子の滑りに伴う变化の直流および交流成 分の寄与を示している。

一方，(16)，(18)式より次の関係が成立する。

$$
i_{f \mathrm{AC}}(t)=K_{f^{\prime}{ }^{\prime} \mathrm{AC}}(t) \text {. }
$$

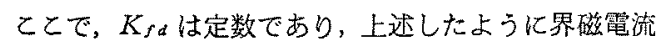
と電機子電流の回転磁界に対する起磁力比を表してい ると考えられる。従って，この上き $\phi_{d}(t)$ は次式で与 えられる。

$$
\begin{aligned}
\psi_{d}(t)= & L_{d f}{ }^{\mathrm{DC}} i_{f \mathrm{DC}}(t)-\left\{L_{d f} \mathrm{AC} K_{f d}\right. \\
& \left.+L_{d}{ }^{\mathrm{AC}}\right\} i_{d \mathrm{AC}}(t) \ldots \ldots \ldots \ldots \ldots \ldots
\end{aligned}
$$

(2) インダクタンスの導出 (22), (24)式で両 刃の直流成分, 交流成分がそれぞれ対応する。従って, (16)，(18)〜 (21)式より，(22)，(24)式中のインダクタ ンス相当量は次式で表される。

$$
\begin{aligned}
& L_{d f^{\mathrm{DC}}}=\frac{\psi_{d \mathrm{DC}}(\infty)-\Psi_{d \mathrm{DC}} e^{-\left(1 / T_{p d}\right)\left(t-t_{0}\right)}}{i_{f}(0)-I_{f \mathrm{DC}} e^{-\left(1 / T_{f}\right)\left(t-t_{0}\right)}} \\
& L_{d f^{\mathrm{AC}}} K_{f d}+L_{d}{ }^{\mathrm{AC}}=\frac{\Psi_{d \mathrm{AC}}}{I_{d \mathrm{AC}}} \\
& L_{q} \mathrm{DC}=-\frac{\psi_{q \mathrm{DC}}\left(t_{0}\right)}{i_{q \mathrm{DC}}\left(t_{0}\right)} \\
& L_{q}^{\mathrm{AC}}=\frac{\Psi_{q \mathrm{AC}}}{I_{q \mathrm{AC}}}
\end{aligned}
$$

ただし， $K_{f d}=I_{f \mathrm{AC}} / I_{d \mathrm{AC}}$ である。これらの各インダク タンス相当量の㬰験における算定結果を表 4 に示す。 これらの結果も5回の脱調試験における算定值を平均 して求めたすのである。

（3）検 討 前項までに得た（22），(24)式の銷 交磁束と電流の関係式は, 実際に空げきにおいてトル ク伝達倚与している銷交磁束と電流の関係を表して いる。これより，従来三相突発短絡試験より得られて いる過渡時の鎖交磁束と電流の関係 ${ }^{(8)}$ が，脱調時にお いては各成分の回転子の同期角速度加らの滑りに伴う 振幅変化と刘応することが明らかとなった。とれは言 い換えると，電気出力の振動で見た瞬間的関係におい ては，従来の関係式が成立しないことを示している。

次に，(25)式で得た脱調時のインダクタンス相当量 の算定侹（表 4) を表 1 の供試発電機の過渡インダタ タンス値之比較すると， $L_{d f} \mathrm{AC}_{f_{d}}+L_{q} \mathrm{AC}$ が $d$ 㖕過 渡インダクタンス $L_{a^{\prime}}$ と, また $L_{q}{ }^{\mathrm{AC}}$ が $q$ 朝過渡イン ダクタンス $L_{q}^{\prime}$ と刘応することが定量的に確かわる ことができる。これは，従来の過渡特性の表現と(22)， (24)式の表現との対応を定量的に裹付けていると考え られる。一方, 各直流成分の時定数に関しては，あま り良く対応しているとは言えない。これは，脱調時に

\begin{tabular}{|c|c|c|}
\hline 数 & 算 定 㨁 & $(\%)$ \\
\hline$L_{d f} \mathrm{DC}$ & $0.08 \mathrm{H}$ & 374 \\
\hline$L_{d f} A C K_{f d}+L_{d} A C$ & $0.0063 \mathrm{H}$ & 29.4 \\
\hline$L_{q} \mathrm{DC}$ & $0.013 \mathrm{H}$ & 60.7 \\
\hline$L_{q} \mathrm{AC}$ & $0.0152 \mathrm{H}$ & $71: 0$ \\
\hline$K_{f d}$ & 19.6 & \\
\hline
\end{tabular}
は三相突発短絡の場合上異なり，発電機之系統側との 電力の授受が行われているととによると考えられる が，明らかではない。しかし，これらの結果は，探り コイルを用いて空げき磁束を测定するととにより，実 目荷時に過渡インダクタンスを測定市るととができる ことを示している。

表 4 脱調時のインダクタンス相当量の算定值

Table 4. Estimated results of the equivalent inductances at the state of asynchronization.

(注) パーセント数墔枕 $6 \mathrm{kVA}, 220 \mathrm{~V}$ をでースとしたすのである。 
以上の検討加ら，従来の過渡時の特性表現が有して いる物理的意味が明らかとなった。すなおち，徉来同 期発電機の瞬時特性として与えられてきた過渡時の特 性表現は，回転子側の生成する磁界上電機子側の生成 する磁界の滑り汇伴って発生する端子量の振幅の振動 の表現となっている。この振動は，上述の滑りによ り, 界磁起磁力比対して電機子反作用起磁力方增磁之 減磁定䌯这し，電機子巻線銷交磁束のうち空げき部に おいでトルク伝達に関与する成分か增減を繰返すとと によって生じる。三相突発短絡時には，電機子側の磁 界が短絡之同時任電機子上に停止し(3)，滑りの速度が 回転子の回転速度之一致するため，乙の滑りに対する 過渡特性か踩時特性と一致することになる。とこる が，脱調時仙電機子侽の起磁力は系統周波数で回軽 し続けるため，本論文に示したように，滑りに対する 䎠渡特性之瞬時特性は異なるととが明らかとなった。 との点に関しては，従来あまり重要視されていなかっ た。これより，従来の特性表現は回転子の滑りに伴う

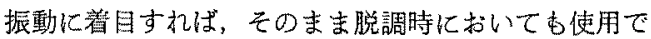

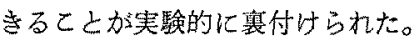

次に，過渡インダクタンスの物理的意味について㭘 討する。従来，同期発電㙨のインダクタンスとして動 作状態ごこに等洒回路に基ついて異なる定義が与えら れてきた。しかし，ての定義には銷交㗪束一定という 纳定が置かれて招り，その物理的実体が明確ではな い。本実駼結果は，同期インダクタンスと過渡インダ クタンスが異なる物理的意味を有するととを示してお り，定態時から過渡時への变化任伴うインダクタンス 值の不連䅌性を説明するものであると教えら机る。 すなわち，同期インダクタンスは回転子の回転仙よる 鎖交磁束之電流の関保を表しているが，過渡インダク タンスは回転子側の生成する起磁力之電機子反作用起 磁力がすべる際の滑り角周波数により鎖交磁束上電流 の振幅が变化する関係を表している。この意味で，過 渡インダクタンスは, 従来の回路理諭に基つく回転子 の回転化よるインダクタンス之異むっており，“二次 のオーダのインダクタンズとも呼ふべき物理量であ る。従って，三相笑発短絡試験比上る過渡インダクタ ンスの算定法は，過滩特性の䁔時特性之起磁力の滑り に対する特性の同一性がうまく利用されていると見る ととができる。

著者らは，空げき磁束の测定結果加ら，発電機内部 磁束分布心過渡時における挙動は，三相突発短絡時之 脱調時で起磁力の滑りに着目すると，非常に類似して いることを定性的に示した(3)(4)。本諭文の結果恃，を れを更に定量的に襄付けたるのとなっている。これ は, 従来の過渡時の特性表現は滑り《着目した表現上 兒ることにより，現実の内部磁束の過渞举動と対心す るととを示している。この結果は，同期発電機の安定 度解析を，現実の発電機動作を支配する内部磁束の挙

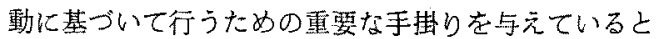

考えられる。

\section{6. 終りに}

本諭文は，同期発電機の過啭時の特性表現の物理的 意味について，脱調時の空げき磁束の測定に基ついて 検討したものである。以下に結果をまよめる。

（1）探りコイルを用いて脱調現象発生時の霄機子 巻線鎖交磁束を算出し, 脱調発展過程に打りる銷交磁 束之電流の実験式より，実負荷状態におりる過渡現象 関して特性表現を得，インダクタンスを算定した。 本諭文で用いた方法は，從来三相哭発短絡試験の端子 量の解析以用いられている方法を抬張適用しだすのて ある。その結果，脱調時の特性表現は，界磁起磁力上 電機子反作用起磁力の滑りに着目する之，従来の三相 突発短絡時の特性表現と対応するととが明ら加となっ た。ただし，時定数に関しては今玆の检討老要する。

（2）従来の過渡時の特性表現は発電機の瞬時特性 として与えられているが，乙れは三相突発短絡の場合 に限られている。界磁起磁力上電機子反作用起磁力 の滑り角速度が同期角速度之異なる場合には，徒来の 特性表現は瞬時特性ではなく，滑りに対する過渡特性 を表しているととが実験的浪明らかとなった。すなわ ち，三相笑発短絡試験による過渡インダクタンスの算 定法は，過渡特性上滑りに対方る過渡特性の同一性を 利用したものであるる言える。

（3）過渡インダクタンスは，上述の滑り角居波数 汇よる銷交磁束と電流の振幅变化の関係を表してお り，同期インダクタンスと物理的意味が異なる。この 結果は，定態時加過渡時への変化に伴うインダクタ ンスの不連綕性を物理的に説明するものである。

ここに得た結果は，今後，負荷変動などの過渡状態 などによいて更に検討を行えば，同期発電機の過渡安 定度の解析を，現実の発電機趿作を支配する物理量て ある磁束の挙動を反映したもの改善する手掛りを与 えていると考元られる。

最後に，日ごる有益な御助言と御指導をいただく， 京都大学松木純也講師，岡田隆夫教授，林 宗明教授 に感謝の意を表します。また，終始暖い御支援を賜り ます関西大学平根喜久教授に，乙の場を汃りて感碀い たします。

(昭和 62 年 4 月 30 日受付)

\section{文献}

(1) 上之圆 ·上田・七原 *金子：電学論 B，102，281 (昭 57 -5)

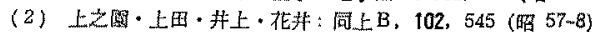

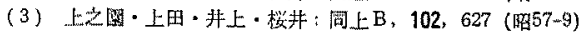

(4) Y. Ueda, T. Hikihara \& C. Uenosono: Ilmenau, DDR, Oct. 29-Nov. 2 (1984)

(5) Y. Ueda, T. Hikihara \& C. Uenosono : Mem. Fac Eng., Kyato Uniz:, 48, No. 2, 178 (1986)

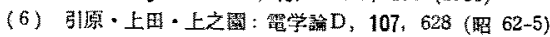

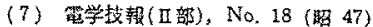

(8) E.W. Kimbark: Power System Stability, Vol, 3 (1956) John Wiley \& Sons. Inc. 